\title{
Transcriptomic Signature of Right Ventricular Failure in Experimental Pulmonary Arterial Hypertension: Deep Sequencing Demonstrates Mitochondrial, Fibrotic, Inflammatory and Angiogenic Abnormalities
}

\author{
Francois Potus ${ }^{1,+} \oplus$, Charles Colin Thomas Hindmarch ${ }^{2,+}$, Kimberly J. Dunham-Snary ${ }^{1}$, \\ Jeff Stafford ${ }^{3}$ and Stephen L. Archer $1,2, *$ (D) \\ 1 Department of Medicine, Queen's University, Kingston, ON K7L3N6, Canada; FP17@queensu.ca (F.P.); \\ kimberly.dunhamsnary@queensu.ca (K.J.D.-S.) \\ 2 Queen's Cardiopulmonary Unit (QCPU), Translational Institute of Medicine (TIME), Department of \\ Medicine, Queen's University, Kingston, ON K7L3N6, Canada; c.hindmarch@queensu.ca \\ 3 Centre for Advanced Computing, Queen's University, Kingston, ON K7L3N6, Canada; \\ jeff.stafford@queensu.ca \\ * Correspondence: stephen.archer@queensu.ca \\ + These authors contributed equally to this work.
}

Received: 13 August 2018; Accepted: 2 September 2018; Published: 12 September 2018

\begin{abstract}
Right ventricular failure (RVF) remains the leading cause of death in pulmonary arterial hypertension (PAH). We investigated the transcriptomic signature of RVF in hemodynamically well-phenotyped monocrotaline (MCT)-treated, male, Sprague-Dawley rats with severe PAH and decompensated RVF (increased right ventricular (RV) end diastolic volume (EDV), decreased cardiac output (CO), tricuspid annular plane systolic excursion (TAPSE) and ventricular-arterial decoupling). RNA sequencing revealed 2547 differentially regulated transcripts in MCT-RVF RVs. Multiple enriched gene ontology (GO) terms converged on mitochondria/metabolism, fibrosis, inflammation, and angiogenesis. The mitochondrial transcriptomic pathway is the most affected in RVF, with 413 dysregulated genes. Downregulated genes included TFAM (-0.45-fold), suggesting impaired mitochondrial biogenesis, CYP2E1 (-3.8-fold), a monooxygenase which when downregulated increases oxidative stress, dehydrogenase/reductase 7C (DHRS7C) (-2.8-fold), consistent with excessive autonomic activation, and polypeptide $N$-acetyl-galactose-aminyl-transferase 13 (GALNT13), a known pulmonary hypertension (PH) biomarker (-2.7-fold). The most up-regulated gene encodes Periostin (POSTN; 4.5-fold), a matricellular protein relevant to fibrosis. Other dysregulated genes relevant to fibrosis include latent-transforming growth factor beta-binding protein 2 (LTBP2), thrombospondin 4 (THBS4). We also identified one dysregulated gene relevant to all disordered transcriptomic pathways, ANNEXIN A1. This anti-inflammatory, phospholipid-binding mediator, is a putative target for therapy in RVF-PAH. Comparison of expression profiles in the MCT-RV with published microarray data from the RV of pulmonary artery-banded mice and humans with bone morphogenetic protein receptor type 2 (BMPR2)-mutations PAH reveals substantial conservation of gene dysregulation, which may facilitate clinical translation of preclinical therapeutic and biomarkers studies. Transcriptomics reveals the molecular fingerprint of RVF to be heavily characterized by mitochondrial dysfunction, fibrosis and inflammation.
\end{abstract}

Keywords: transcriptomics; mitochondria; metabolism; TFAM; CYP2E1; GALNT13; ANXA1; periostin; LTBP2; THBS4 


\section{Introduction}

Right ventricular (RV) function is the most important predictor of morbidity and mortality in pulmonary arterial hypertension (PAH) [1]. Current therapeutics target the pulmonary vasculature and while they provide important functional improvement, PAH survival remains poor $(\sim 50 \%$ at 5-years) [2-4]. A better understanding of RVF and identification of new therapeutic targets is crucial to improving patient survival.

RVF results from the dysfunction of multiple overlapping systems, including mitochondria, metabolism, fibrosis, inflammation, and angiogenesis [5,6]. Fibrosis, characterized by collagen accumulation and excessive extracellular remodelling is closely linked with increased RV stiffness and subsequent deterioration of RV function [7]. There is a clear correlation between RV fibrosis and reduced RV function [8-10]. Conversely, reductions in fibrosis correlate with improvements in RV function [11,12].

Inflammation also contributes to RVF. Increased plasma levels of C-reactive protein (CRP) and the inflammatory cytokine interleukin-6 (IL-6) are associated with reduced RV function in human PAH $[13,14]$. Scleroderma-associated PAH (SSc-PAH) is a condition in which autoimmunity is a hallmark. Affected patients display RV dysfunction that is disproportionate to PA pressure and have a worse prognosis than patients with idiopathic PAH [15].

Angiogenesis, a process closely related to inflammation and fibrosis $[16,17]$, is disrupted in $\mathrm{PAH}$, resulting in reduced capillary density in both the pulmonary vasculature and RV. Capillary rarefaction in the RV is associated with dysregulation of VEGF, Angiopoietin and SPRED-1 [6,18,19]. Conversely, increased angiogenesis and RV capillary density by epigenetic downregulation of SPRED-1 in a preclinical model of PAH is associated with improved RV function and decreased fibrosis [19]. Moreover, virus-mediated delivery of angiogenic factors is protective in animal models of PAH [20,21].

Our group has previously reported the contribution of mitochondrial/metabolic dysregulation to the aetiology of RVF in PAH. Interestingly, there are parallel mitochondrial/metabolic abnormalities in the pulmonary vasculature and heart in $\mathrm{PAH}$, making this a particularly appealing therapeutic target. RVF is associated with a metabolic shift away from oxidative fatty acid or glucose metabolism toward a pattern of metabolism characterized by increased uncoupled, aerobic glycolysis. This Warburg metabolism is multifactorial caused in part by upregulation of pyruvate dehydrogenase kinase (PDK) and inhibition of phosphodiesterase of pyruvate dehydrogenase (PDH). There is also increased glutaminolysis (reflecting ischemia-induced cMyc activation) in RVF and abnormalities in mitochondrial complexes II, III and IV (CXI; II; IV) [22-24]. Decreased mitochondrial density and organellar structural changes have also been reported in RV of PAH animal models [25,26]. It is not only the RV myocyte and coronary arteries that are adversely affected in the PAH RV; we have demonstrated that RV fibroblasts from monocrotaline (MCT) rats display increased mitochondrial fission, which is associated with increased fibroblast proliferation and collagen deposition [27].

Here, we provide a comprehensive hemodynamic of RVF and demonstrate the corresponding transcriptomic signature of RVF in the monocrotaline-induced (MCT)-PAH model [28]. Using this unbiased strategy, we show marked dysregulation of four pathways: mitochondria/metabolism, fibrosis, inflammation and angiogenesis.

\section{Results}

\subsection{Characterization of RVF in MCT-PAH}

RV function was quantified using non-invasive echocardiography prior to sacrifice and a terminal right heart catheterization (RHC), both performed in anesthetised, closed-chest rats (Figure 1A,B and Table 1). Representative PV-loop and pressure measurements from Ctrl and MCT rats are shown in Figure 1A,B. Compared to control, MCT displayed significant pulmonary hypertension, characterized by increased mean pulmonary arterial pressure (mPAP), right ventricular systolic pressure (RVSP), total pulmonary resistance (TPR), arterial elastance (Ea) and shortened pulmonary artery acceleration 
time (PAAT). MCT rats displayed right ventricular hypertrophy (RVH), as assessed by the Fulton index and right ventricle free wall (RVFW) thickness, and increased end diastolic volume (EDV). MCT rats had a significant decrease in cardiac output (CO). MCT animals displayed systolic dysfunction characterized by decreased tricuspid annular plane systolic excursion (TAPSE), ejection fraction (EF), and increased peak rate pressure decline $\left(\mathrm{dP} / \mathrm{dt}_{\max }\right)$ and stroke work (SW) as well as diastolic dysfunction suggested by increased $\mathrm{dP} / \mathrm{dt}_{\max }$ and Tau Mirnsky. Independent of pre- and afterload, RVs from MCT rats had decreased contractility (increased preload recruited stroke work (PRSW) and pressure volume area-EDV relationship (PVA/EDV)) and impaired cardiovascular efficiency (decreased ventricular-arterial coupling, ventricular arterial coupling (Emax/Ea)), indicating that MCT RV dysfunction is not solely caused by increased afterload (Table 1).

A)

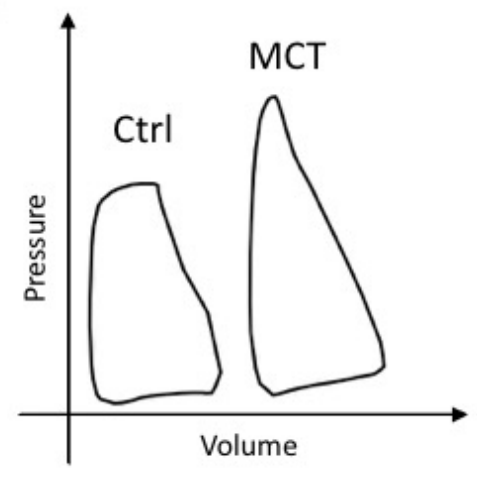

B)

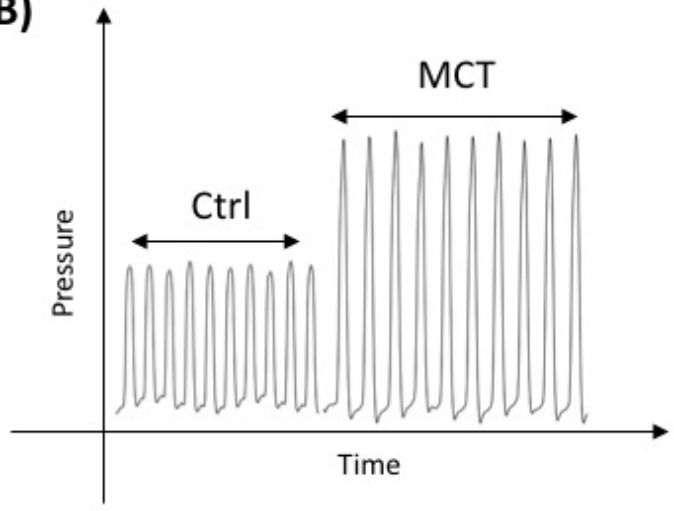

Figure 1. (A) Representative pressure volume loop and (B) pressure trace in monocrotaline (MCT) and control (Ctrl) animals.

Table 1. Hemodynamic characterization of RHF in MCT in MCT $(n=8)$ vs. Ctrl $(n=15)$ rats. CO, cardiac output; $\mathrm{dP} / \mathrm{dt}_{\max }$, peak rate pressure rise; $\mathrm{dP} / \mathrm{dt}_{\min }$, peak rate pressure decline; Ea, arterial elastance; EDV, end diastolic volume; EF, ejection fraction; Emax, maximal elastance; Emax/Ea, ventricular arterial coupling; HR, heart rate; $\mathrm{mPAP}$, mean pulmonary arterial pressure; PAAT, pulmonary artery acceleration time; PRSW, preload recruited stroke work (slope of stroke work-EDV relationship); PVA/EDV, pressure volume area-EDV relathionship; RVSP, right ventricular systolic pressure; RVWF, right ventricle free wall; SW, stroke work; TAPSE, tricuspid annular plane systolic excursion; Tau Mirnsky, relaxation time constante calculated by Mirnsky method (time time requiered to RV pressure to fall to one half of its value at ESP); TPR, total pulmonary resistance (mPAP/CO). Unpaired $t$-test; data expressed as mean \pm SEM. ${ }^{*} p<0.05$.

\begin{tabular}{ccc}
\hline & Ctrl $(\boldsymbol{n}=\mathbf{1 5})$ & MCT $(\boldsymbol{n}=\mathbf{8})$ \\
\hline & Parameters & \\
HR $(\mathrm{BPM})$ & $308.8(7.33)$ & $248.9(18.85)$ \\
$\mathrm{RVSP}(\mathrm{mmHg})$ & $23.51(0.9742)$ & $51.33 *(6.589)$ \\
$\mathrm{mPAP}(\mathrm{mmHg})$ & $16.34(0.5943)$ & $33.31 *(4.019)$ \\
EDV $(\mu \mathrm{L})$ & $241.4(21.12)$ & $424.8 *(43.04)$ \\
$\mathrm{SV}(\mu \mathrm{L})$ & $296.3(8.3)$ & $278.3(23.97)$ \\
$\mathrm{CO}(\mu \mathrm{L} / \mathrm{min})$ & $91,650(2672)$ & $70,209 *(4425)$ \\
$\mathrm{Ea}(\mathrm{mmHg} / \mu \mathrm{L})$ & $0.1871(0.01736)$ & $0.26 *(0.01962)$ \\
Emax $(\mathrm{mmHg} / \mu \mathrm{L})$ & $0.2828(0.04747)$ & $0.199(0.05393)$ \\
PAAT $(\mathrm{ms})$ & $32.72(0.8737)$ & $21.17 *(0.7032)$ \\
$\mathrm{RVFW}(\%)$ & $106.7(3.926)$ & $28.33 *(8.476)$ \\
$\mathrm{TPR}(\mathrm{mmHg} / \mathrm{mL} / \mathrm{min})$ & $0.1911(0.007972)$ & $0.4552 *(0.04644)$ \\
Fulton index & $0.2725(0.0054)$ & $0.6354 *(0.0302)$ \\
\hline & Systolic Indices & \\
TAPSE $(\mathrm{mm})$ & $3.088(0.05361)$ & $2.16 *(0.1136)$ \\
$\mathrm{EF}(\%)$ & $66.36(1.769)$ & $52.69 *(2.343)$ \\
\hline
\end{tabular}


Table 1. Cont.

\begin{tabular}{|c|c|c|}
\hline & $C \operatorname{trl}(n=15)$ & $\operatorname{MCT}(n=8)$ \\
\hline $\mathrm{dP} / \mathrm{dt}_{\max }(\mathrm{mmHg} / \mathrm{s})$ & $651.1(22.4)$ & $1048 *(117.8)$ \\
\hline SW (mJoule) & $0.4639(0.03557)$ & $0.9711 *(0.188)$ \\
\hline \multicolumn{3}{|l|}{ Diastolic indices } \\
\hline $\mathrm{dP} / \mathrm{dt}_{\min }(-\mathrm{mmHg} / \mathrm{s})$ & $577.4(20.42)$ & $1063 *(151.9)$ \\
\hline Tau Mirnsky (mS) & $29.11(0.3685)$ & $38.46 *(2.082)$ \\
\hline \multicolumn{3}{|l|}{ Contractibility indices } \\
\hline PRSW (mmHg) & $14.12(0.6412)$ & $23.38 *(2.75)$ \\
\hline PVA/EDV (mmHg) & $0.001571(0.0001373)$ & $0.002625 *(0.0003239)$ \\
\hline \multicolumn{3}{|c|}{ Ventricular-Arterial Coupling } \\
\hline $\mathrm{Emax} / \mathrm{Ea}$ & $1.516(0.1886)$ & $0.7298 *(0.1884)$ \\
\hline
\end{tabular}

2.2. RVF Is Associated with Increased Fibrosis, Inflammation Decreased Angiogenesis and Mitochondrial/Metabolic Dysfunction

Confirming previous reports [5], MCT-RVF was associated with RV fibrosis, as assessed by increased collagen deposition (Figure 2A). Inflammation was also increased in MCT RVs, as measured by an increase in CD68 (monocyte cell marker, Figure 2B). MCT also resulted in RV capillary rarefaction, evident from the global diminution of CD31, an endothelial cell marker (Figure 2C). There was a significant functional mitochondrial defect in MCT RVs, indicated by decreased activity of PDH, Complex I and Complex IV (Figure 3A-C).

A)
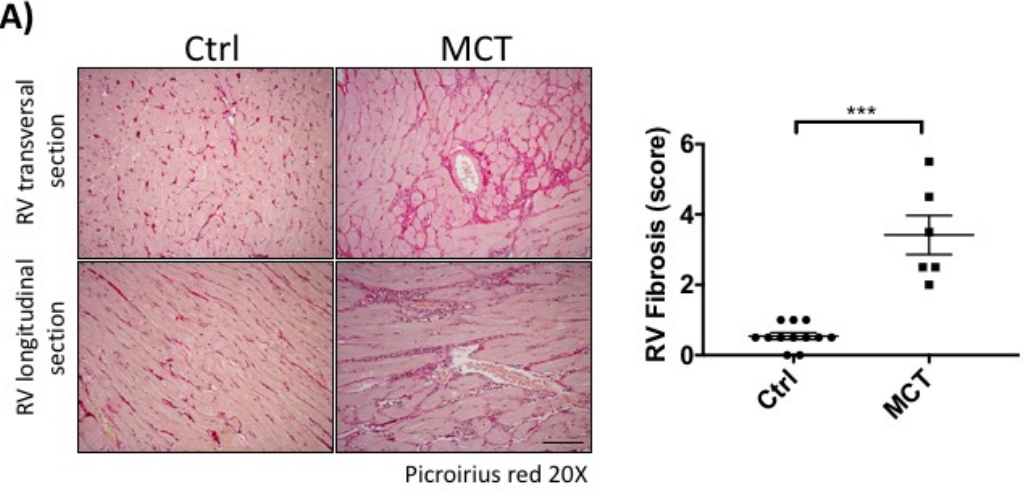

B)

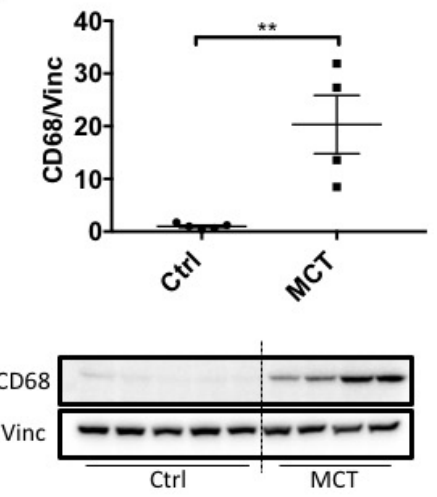

C)

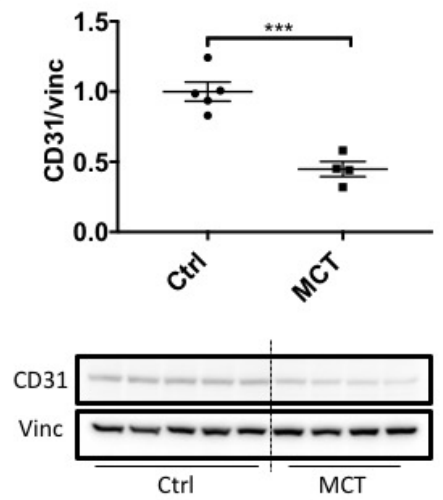

Figure 2. Right heart failure is associated with increased fibrosis, inflammation and angiogenic defect. (A) Fibrosis assessed by picrosirius red staining of RV from MCT $(n=8)$ vs. Ctrl $(n=15)$ rats. Scale bar in black represent $100 \mu \mathrm{m}$; (B) Inflammation assessed via CD68 immunoblot ( $n \geq 4$ per group); (C) Capillary density assessed by CD31 immunoblot ( $n \geq 4$ per group). Unpaired $t$-test; data expressed as mean \pm SEM. ${ }^{* *} p<0.01 ;{ }^{* * *} p<0.001$. 
A)

B)
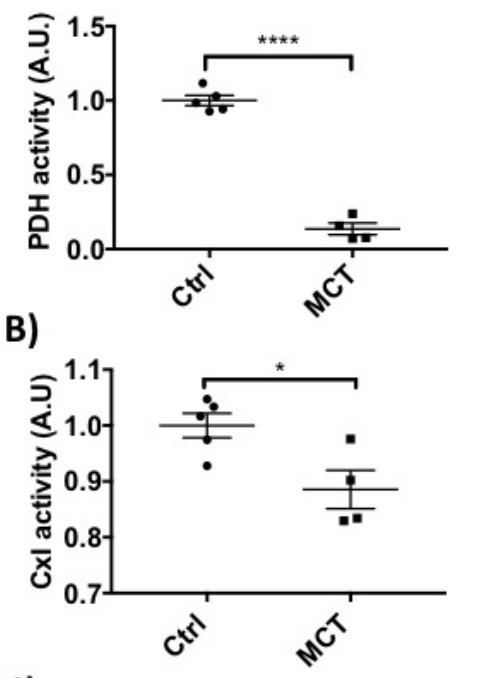

C)

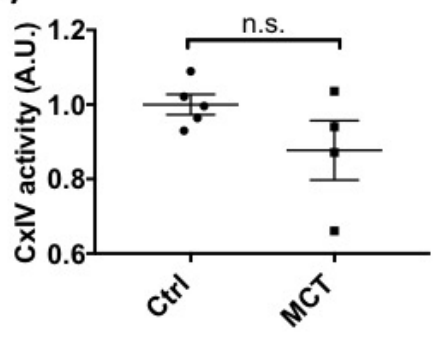

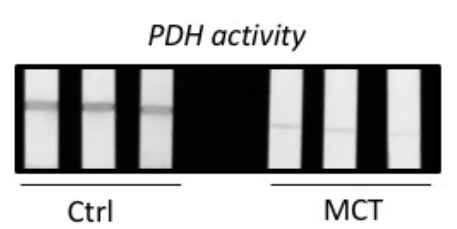
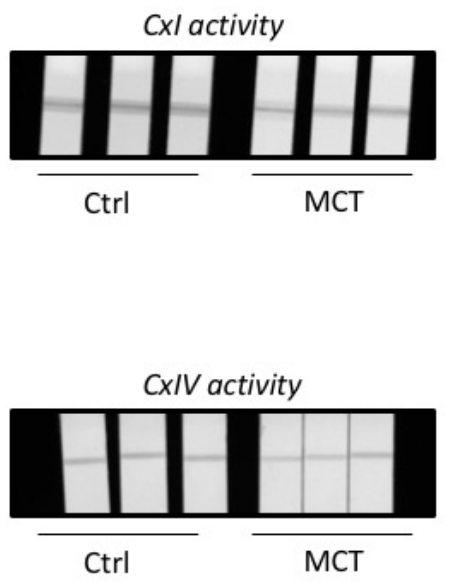

Figure 3. Right heart failure is associated with metabolic and mitochondrial dysfunction. (A) pyruvate dehydrogenase (PDH) activity; (B) mitochondrial complex I (CxI); and (C) mitochondrial complex IV (CxIV) activity, all measured via dipstick assay ( $n \geq 4$ per group). Unpaired $t$-test; data expressed as mean \pm SEM. n.s.-not significant, ${ }^{*} p<0.05 ;{ }^{* * * *} p<0.0001$.

\subsection{RNA Sequencing}

RNA sequencing revealed 2546 transcripts that were significantly and differentially regulated in the RV as a consequence of MCT treatment (Table 2, Table S1). To validate this sequencing-derived dataset, we used quantitative polymerase chain reaction (PCR) and successfully validated the 6 most significantly and differentially regulated genes in the arrays, using cDNA extracted from an independent group of animals (Table 3).

Table 2. Enriched functional analysis. List of significantly enriched terms that describe genes differentially expressed in rat RVF-PAH. List represents enriched terms that can broadly be classified as "Mitochondria/Metabolism", "Fibrosis", or "Inflammation".

\begin{tabular}{ccccc}
\hline Term & Category & Function & $\begin{array}{c}\text { Gene } \\
\text { Count }\end{array}$ & $p$ Value \\
\hline GO:0005739 mitochondrion & GOTERM_CC_DIRECT & MitoMetabolism & 414 & $1.85 \times 10^{-56}$ \\
Mitochondrion & UP_KEYWORDS & MitoMetabolism & 196 & $4.16 \times 10^{-37}$ \\
$\begin{array}{c}\text { GO:0005743 mitochondrial inner } \\
\text { membrane }\end{array}$ & GOTERM_CC_DIRECT & MitoMetabolism & 104 & $1.37 \times 10^{-22}$ \\
$\begin{array}{c}\text { Mitochondrion inner membrane } \\
\text { transit peptide:Mitochondrion } \\
\text { rno01100:Metabolic pathways } \\
\text { rno00190:Oxidative } \\
\text { phosphorylation }\end{array}$ & UP_KEYWORDS & MitoMetabolism & 65 & $7.55 \times 10^{-18}$ \\
$\begin{array}{c}\text { GO:0005747 mitochondrial } \\
\text { respiratory chain complex I }\end{array}$ & KEGG_PATHWAY & MitoMetabolism & 279 & $3.38 \times 10^{-15}$ \\
\hline
\end{tabular}


Table 2. Cont.

\begin{tabular}{|c|c|c|c|c|}
\hline Term & Category & Function & $\begin{array}{l}\text { Gene } \\
\text { Count }\end{array}$ & $p$ Value \\
\hline Oxidoreductase & UP_KEYWORDS & MitoMetabolism & 109 & $3.00 \times 10^{-11}$ \\
\hline \multirow{2}{*}{$\begin{array}{c}\text { Electron transport } \\
\text { GO:0055114 oxidation-reduction } \\
\text { process }\end{array}$} & UP_KEYWORDS & MitoMetabolism & 31 & $7.73 \times 10^{-11}$ \\
\hline & GOTERM_BP_DIRECT & MitoMetabolism & 129 & $1.09 \times 10^{-8}$ \\
\hline $\begin{array}{l}\text { GO:0006979 response to } \\
\text { oxidative stress }\end{array}$ & GOTERM_BP_DIRECT & MitoMetabolism & 44 & $1.40 \times 10^{-8}$ \\
\hline Ubiquinone & UP_KEYWORDS & MitoMetabolism & 18 & $2.05 \times 10^{-8}$ \\
\hline Respiratory chain & UP_KEYWORDS & MitoMetabolism & 19 & $4.37 \times 10^{-7}$ \\
\hline $\begin{array}{c}\text { GO:0008137 NADH } \\
\text { dehydrogenase (ubiquinone) } \\
\text { activity }\end{array}$ & GOTERM_MF_DIRECT & MitoMetabolism & 18 & $4.64 \times 10^{-7}$ \\
\hline $\begin{array}{c}\text { GO:0005759 mitochondrial } \\
\text { matrix }\end{array}$ & GOTERM_CC_DIRECT & MitoMetabolism & 43 & $6.38 \times 10^{-7}$ \\
\hline \multirow{2}{*}{$\begin{array}{c}\text { Tricarboxylic acid cycle } \\
\text { GO:0000086 G2/M transition of } \\
\text { mitotic cell cycle }\end{array}$} & UP_KEYWORDS & MitoMetabolism & 12 & $9.93 \times 10^{-6}$ \\
\hline & GOTERM_BP_DIRECT & MitoMetabolism & 16 & $1.11 \times 10^{-5}$ \\
\hline $\begin{array}{c}\text { GO:0006099 tricarboxylic acid } \\
\text { cycle }\end{array}$ & GOTERM_BP_DIRECT & MitoMetabolism & 14 & $1.16 \times 10^{-5}$ \\
\hline $\begin{array}{c}\text { GO:0006635 fatty acid } \\
\text { beta-oxidation }\end{array}$ & GOTERM_BP_DIRECT & MitoMetabolism & 18 & $1.27 \times 10^{-5}$ \\
\hline $\begin{array}{l}\text { GO:0050660 flavin adenine } \\
\text { dinucleotide binding }\end{array}$ & GOTERM_MF_DIRECT & MitoMetabolism & 22 & $5.42 \times 10^{-5}$ \\
\hline \multirow{3}{*}{$\begin{array}{c}\text { FAD } \\
\text { GO:0031966 mitochondrial } \\
\text { membrane } \\
\text { NAD }\end{array}$} & UP_KEYWORDS & MitoMetabolism & 26 & $5.49 \times 10^{-5}$ \\
\hline & GOTERM_CC_DIRECT & MitoMetabolism & 27 & $6.32 \times 10^{-5}$ \\
\hline & UP_KEYWORDS & MitoMetabolism & 34 & $1.43 \times 10^{-4}$ \\
\hline Flavoprotein & UP_KEYWORDS & MitoMetabolism & 26 & $1.89 \times 10^{-4}$ \\
\hline rno00020:Citrate cycle (TCA cycle) & KEGG_PATHWAY & MitoMetabolism & 14 & $2.28 \times 10^{-4}$ \\
\hline \multirow{2}{*}{$\begin{array}{l}\text { ATP synthesis } \\
\text { Mitochondrion outer membrane }\end{array}$} & UP_KEYWORDS & MitoMetabolism & 8 & $2.47 \times 10^{-4}$ \\
\hline & UP_KEYWORDS & MitoMetabolism & 20 & $8.23 \times 10^{-4}$ \\
\hline \multicolumn{3}{|c|}{ TOTAL GENES (excluding duplicates) } & \multicolumn{2}{|r|}{647} \\
\hline GO:0031012 extracellular matrix & GOTERM_CC_DIRECT & Fibrosis & 72 & $5.83 \times 10^{-12}$ \\
\hline GO:0030027 lamellipodium & GOTERM_CC_DIRECT & Fibrosis & 47 & $3.85 \times 10^{-9}$ \\
\hline GO:0005925 focal adhesion & GOTERM_CC_DIRECT & Fibrosis & 90 & $4.02 \times 10^{-9}$ \\
\hline Actin-binding & UP_KEYWORDS & Fibrosis & 48 & $4.60 \times 10^{-9}$ \\
\hline Cytoskeleton & UP_KEYWORDS & Fibrosis & 109 & $8.70 \times 10^{-9}$ \\
\hline $\begin{array}{c}\text { GO:0051015 actin filament } \\
\text { binding }\end{array}$ & GOTERM_MF_DIRECT & Fibrosis & 39 & $5.91 \times 10^{-7}$ \\
\hline Extracellular matrix & UP_KEYWORDS & Fibrosis & 35 & $5.50 \times 10^{-6}$ \\
\hline \multirow{4}{*}{$\begin{array}{l}\text { GO:0005604 basement membrane } \\
\text { GO:0005884 actin filament } \\
\text { GO:0042060 wound healing } \\
\text { rno04510:Focal adhesion }\end{array}$} & GOTERM_CC_DIRECT & Fibrosis & 28 & $9.53 \times 10^{-6}$ \\
\hline & GOTERM_CC_DIRECT & Fibrosis & 24 & $9.77 \times 10^{-6}$ \\
\hline & GOTERM_BP_DIRECT & Fibrosis & 34 & $1.09 \times 10^{-5}$ \\
\hline & KEGG_PATHWAY & Fibrosis & 54 & $1.34 \times 10^{-5}$ \\
\hline \multirow{2}{*}{$\begin{array}{c}\text { GO:0031100 organ regeneration } \\
\text { Microtubule }\end{array}$} & GOTERM_BP_DIRECT & Fibrosis & 27 & $1.77 \times 10^{-5}$ \\
\hline & UP_KEYWORDS & Fibrosis & 39 & $2.53 \times 10^{-5}$ \\
\hline $\begin{array}{l}\text { GO:0005578 proteinaceous } \\
\text { extracellular matrix }\end{array}$ & GOTERM_CC_DIRECT & Fibrosis & 54 & $4.28 \times 10^{-5}$ \\
\hline GO:0005874 microtubule & GOTERM_CC_DIRECT & Fibrosis & 51 & $5.13 \times 10^{-5}$ \\
\hline GO:0002102 podosome & GOTERM_CC_DIRECT & Fibrosis & 13 & $1.49 \times 10^{-4}$ \\
\hline $\begin{array}{l}\text { rno04512:ECM-receptor } \\
\text { interaction }\end{array}$ & KEGG_PATHWAY & Fibrosis & 27 & $1.83 \times 10^{-4}$ \\
\hline \multirow{2}{*}{$\begin{array}{l}\text { GO:0031252 cell leading edge } \\
\text { rno04810:Regulation of actin } \\
\text { cytoskeleton }\end{array}$} & GOTERM_CC_DIRECT & Fibrosis & 18 & $4.54 \times 10^{-4}$ \\
\hline & KEGG_PATHWAY & Fibrosis & 50 & $5.84 \times 10^{-4}$ \\
\hline Collagen & UP_KEYWORDS & Fibrosis & 18 & $7.28 \times 10^{-4}$ \\
\hline \multicolumn{2}{|c|}{$\begin{array}{r}\text { Inflammatory response } \\
\text { TOTAL GENES (excluding duplicates) }\end{array}$} & Inflammation & 24 & $\begin{array}{l}412 \\
2.35 \times 10^{-5} \\
24\end{array}$ \\
\hline
\end{tabular}


Table 3. RNA sequencing validation. PCR validation in independent animals for the the top six genes related genes differentially expressed in RV of rat RVF-PAH vs. control ( $n \geq 6$ per group).

\begin{tabular}{|c|c|c|c|c|c|}
\hline \multirow{2}{*}{ Gene } & \multirow{2}{*}{$\begin{array}{c}\text { Functional } \\
\text { Pathway }\end{array}$} & \multirow{2}{*}{$\begin{array}{c}\begin{array}{c}\text { Sequencing } \\
\text { (Ctrl/MCT) }\end{array} \\
\text { (log) Mean Diff. }\end{array}$} & \multicolumn{3}{|c|}{ PCR Validation (Ctrl/MCT) } \\
\hline & & & (log) Mean Diff. & SE of Diff. & Adjusted $p$ Value \\
\hline POSTN & Cell Adhesion & 4.564263838 & 4.326 & 1.213 & 0.0065 \\
\hline THBS4 & $\begin{array}{l}\text { Angiogenesis } \\
\text { Fibrosis }\end{array}$ & 4.401212936 & 6.798 & 1.248 & $<0.0001$ \\
\hline LTBP2 & Fibrosis & 4.16038822 & 3.545 & 1.112 & 0.0163 \\
\hline RND1 & Cell Adhesion & 2.639368653 & 2.687 & 0.9778 & 0.0451 \\
\hline$S C N 3 B$ & Ion Transport & 2.587455526 & 3.327 & 1.06 & 0.0183 \\
\hline CNTFR & $\begin{array}{c}\text { Signal } \\
\text { Transduction }\end{array}$ & -2.883345535 & -5.146 & 1.352 & 0.0036 \\
\hline
\end{tabular}

\subsection{Functional Annotation of the MCT RV Transcriptome}

In order to understand the global function of our data, we performed a Functional Annotation analysis using the Database for Annotation, Visualization and Integrated Discovery (DAVID) [29]. This revealed multiple enriched terms, many of which converged on functions that describe mitochondria/metabolism, fibrosis and inflammation (Table 2, Table S2). The most significant altered gene ontology (GO) terms related to mitochondria (GO: 0005739; $p=3.5 \times 10^{-53}$ ). There were 413 dysregulated mitochondrial-relevant genes in the MCT RV. We validated 15 of the expression changes with qPCR in an independent group of animals (Table 4, Table S1). We then filtered this list and identified a broad list of genes annotated under: Mitochondria/Metabolism, Fibrosis and Inflammation (Table S3). "Angiogenesis" did not appear via DAVID analysis, so a gene list associated with the Gene Ontology term Angiogenesis (GO: 0001525, Table S4) was imported and our MCT regulated gene list sorted accordingly (Table S1).

Table 4. RNA sequencing validation. PCR validation in independent animals for the top mitochondriarelated genes differentially expressed in RV of rat RVF-PAH vs. control ( $n \geq 6$ per group).

\begin{tabular}{|c|c|c|c|c|c|}
\hline \multirow{2}{*}{ Gene } & \multirow{2}{*}{$\begin{array}{l}\text { Functional } \\
\text { Pathway }\end{array}$} & \multirow{2}{*}{$\begin{array}{c}\begin{array}{l}\text { Sequencing } \\
\text { (Ctrl/MCT) }\end{array} \\
\text { (log) Mean Diff. }\end{array}$} & \multicolumn{3}{|c|}{ PCR Validation (Ctrl/MCT) } \\
\hline & & & (log) Mean Diff. & SE of Diff. & Adjusted $p$ Value \\
\hline PRSS35 & mito/metabolism & 4.23 & 4.31 & 0.8278 & 0.0001 \\
\hline$C D K 1$ & $\begin{array}{c}\text { fibrosis } \\
\text { mito/metabolism }\end{array}$ & 2.11 & 0.5525 & 0.1917 & 0.0342 \\
\hline ADAM12 & $\begin{array}{l}\text { angiogenesis } \\
\text { mito/metabolism }\end{array}$ & 2.03 & 0.8509 & 0.2286 & 0.005 \\
\hline$B C A T 1$ & mito/metabolism & 1.68 & 0.451 & 0.1891 & 0.1005 \\
\hline$L D H D$ & mito/metabolism & -1.51 & -0.8941 & 0.26 & 0.0089 \\
\hline$A D H 1$ & $\begin{array}{c}\text { fibrosis } \\
\text { mito/metabolism }\end{array}$ & -1.55 & -0.8194 & 0.2765 & 0.0294 \\
\hline EHHADH & mito/metabolism & -1.56 & -0.9721 & 0.2564 & 0.0038 \\
\hline GSTA4 & mito/metabolism & -1.57 & -0.7991 & 0.2441 & 0.0133 \\
\hline ECI1 & mito/metabolism & -1.62 & -0.8955 & 0.25 & 0.0063 \\
\hline$A C A A 2$ & mito/metabolism & -1.63 & -0.8883 & 0.2471 & 0.0061 \\
\hline MACROD1 & mito/metabolism & -1.8 & -0.9501 & 0.2723 & 0.0079 \\
\hline UCP3 & mito/metabolism & -1.86 & -0.9768 & 0.3092 & 0.0057 \\
\hline$H A D H$ & mito/metabolism & -2.12 & -0.9813 & 0.2654 & 0.0048 \\
\hline CYP2E1 & mito/metabolism & -3.9 & -6.394 & 1.469 & 0.0009 \\
\hline DECR1 & mito/metabolism & -1.42 & -0.8718 & 0.2272 & 0.0034 \\
\hline
\end{tabular}




\subsection{Comparison with Mouse and Human RV Transcriptomic Data}

We mined published microarray data available from the National Centre for Biotechnology Information (NCBI) Gene-Expression-Omnibus (GEO). We obtained data from a mouse model of chronic RV outflow tract obstruction and RVH induced by pulmonary artery banding (PAB; 6-weeks, $n=2$ and controls, $n=2$; Accession: GSE30428; Table S5) [30] and from PAH patients with BMPR2 mutations vs. controls (postmortem RV expression data, $n=2$ per group; Accession: GSE67492; Table S6) [31]. We used GEO2R to identify differentially regulated genes in each of these experiments and compared these expression profiles to our rat MCT RV profile (Table S1). We identified genes as being common to rat and mouse (Table S7; 930) or rat and human (Table S8; 867) based on a loose $p$-value filter of $p<0.1$. In total, 347 genes were commonly regulated between the rat MCT RV, mouse PAB RV and human BMPR2 RV (Table S9). When these 347 genes were compared to the original annotated gene lists (Tables S3 and S4), 80 in "Fibroblast" (Table S10; Figure 4B), 92 were present in "Mitochondria/Metabolism" (Table S11; Figure 4A), 15 in "Inflammation" (Table S12; Figure 4C) and 22 in "Angiogenesis" (Table S13; Figure 4D). Several of these key genes were overlapping between pathways (Tables S3 and S4; Figure 5). 
A)

Mitochondrial/metabolic
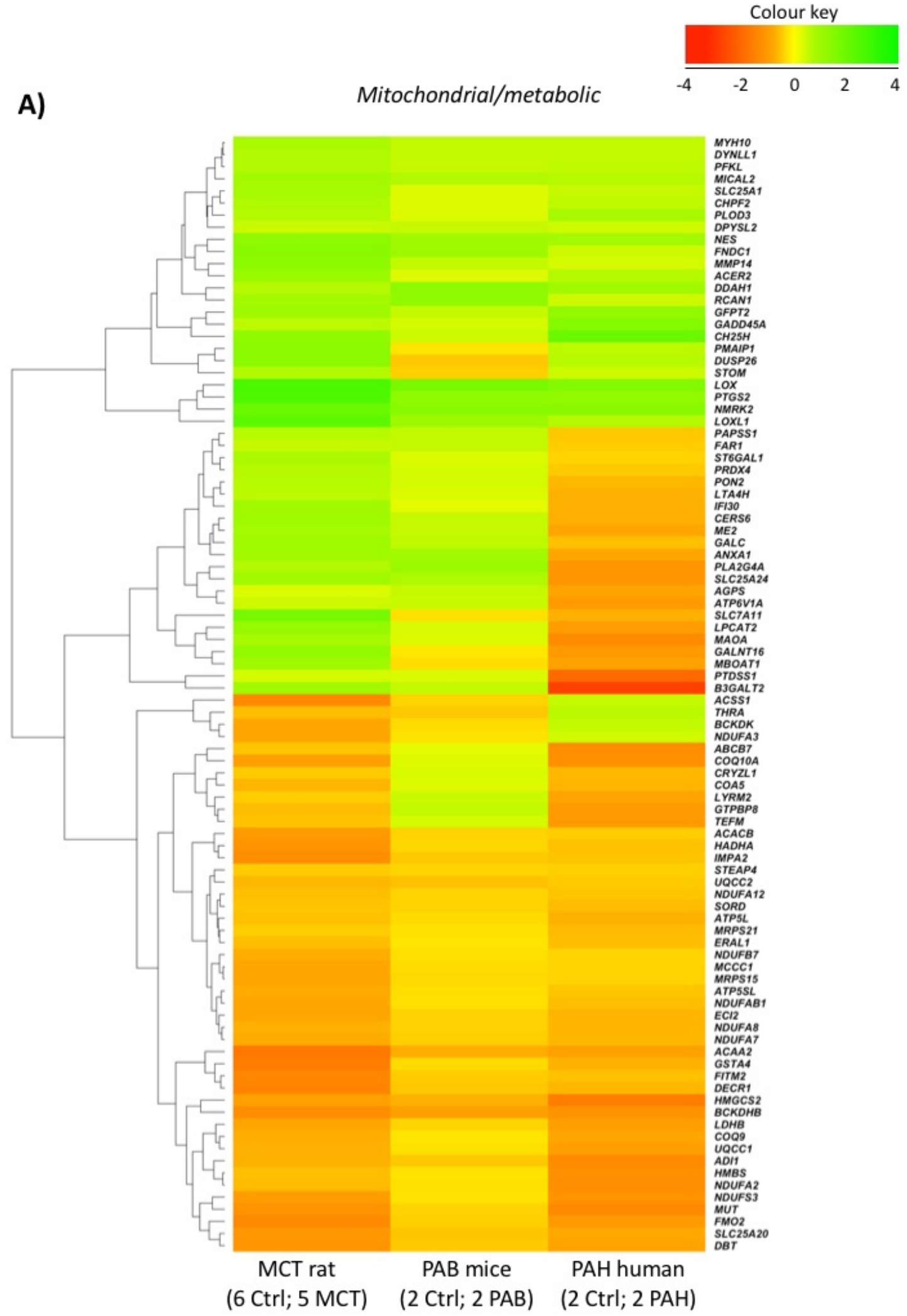

Figure 4. Cont. 
B)

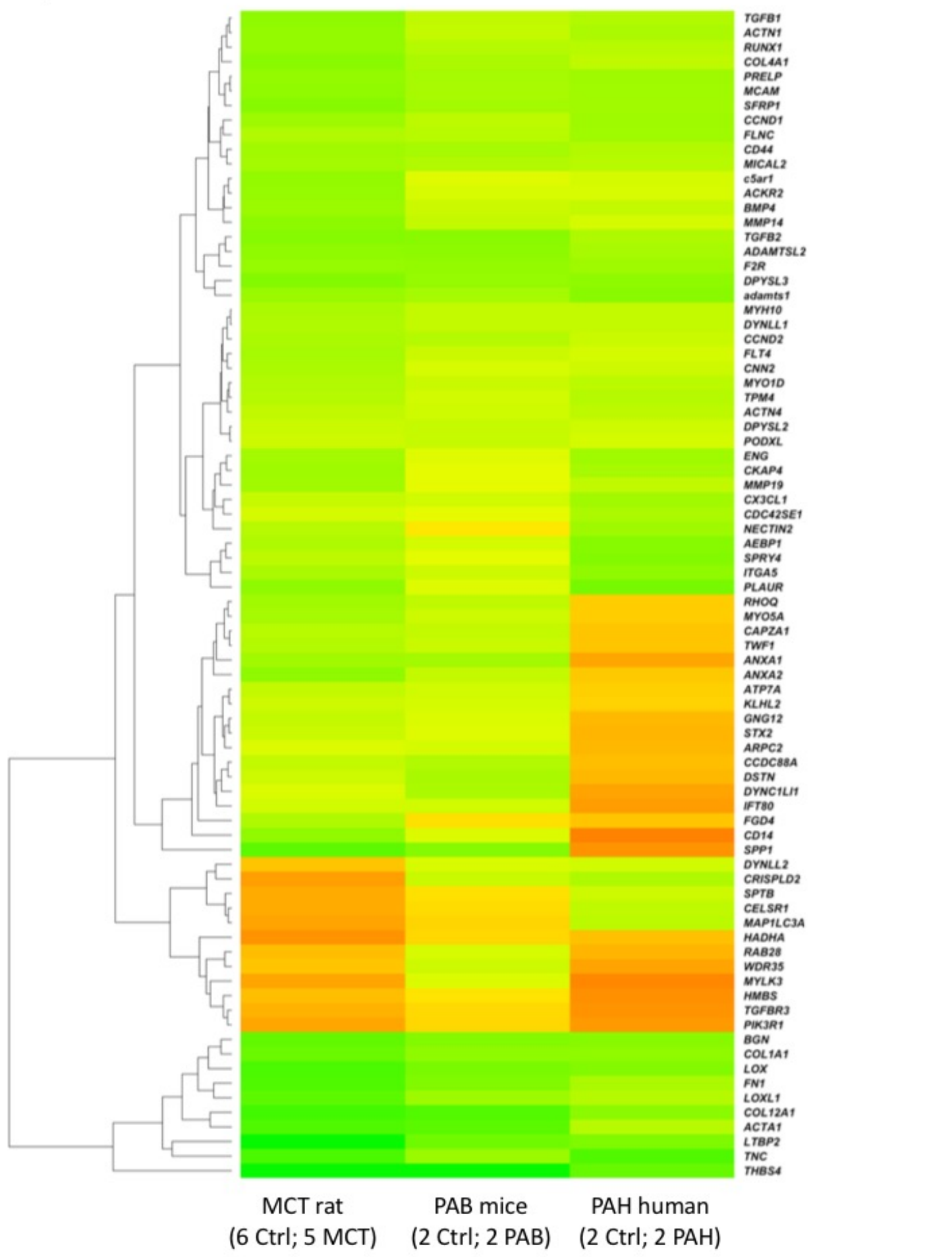

Figure 4. Cont. 


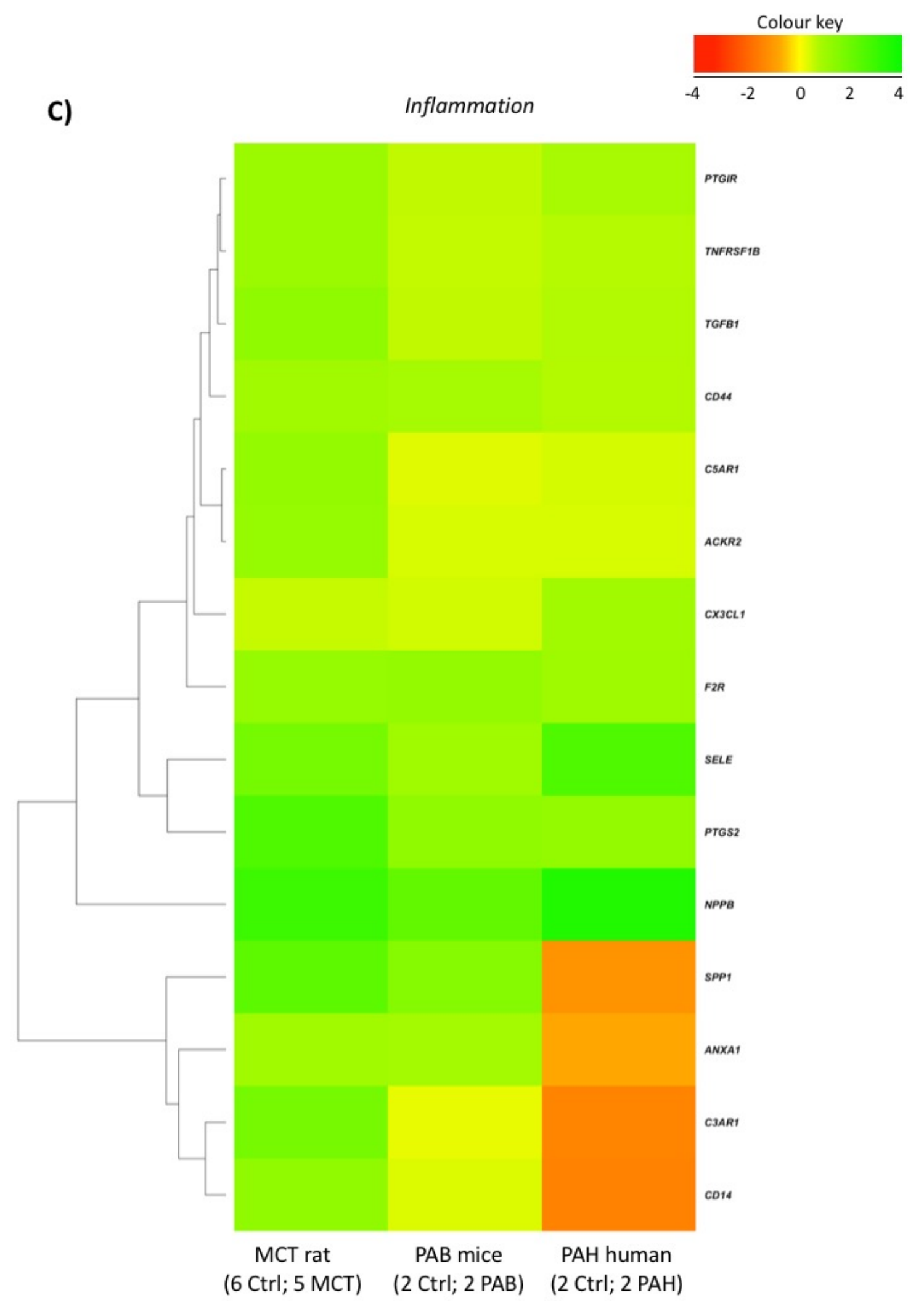

Figure 4. Cont. 


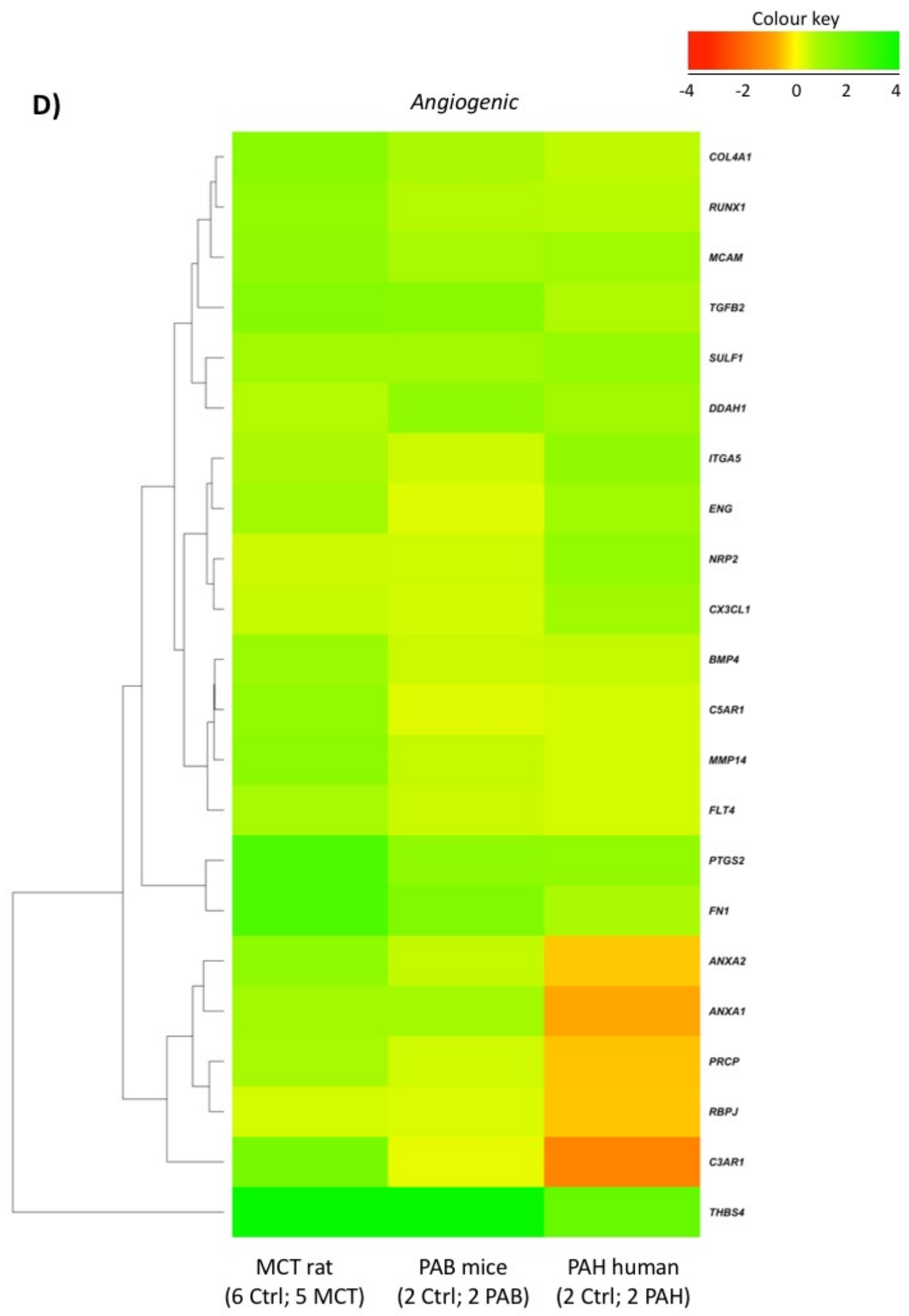

Figure 4. Gene expression changes in the MCT rat, PAB mouse and human BMPR2-PAH. Log2fold differentially-regulated genes in enriched lists: (A) Mitochondria/Metabolism, (B) Fibrosis, (C) Inflammation and (D) Angiogenesis, in the MCT rat RV, mouse pulmonary artery-banded RV ( $n=2$, GSE30428) [30], and human BMPR2-PAH ( $n=2$, GSE67492) [31]. Mouse and human microarrays analysed using NCBI GEOR2. 


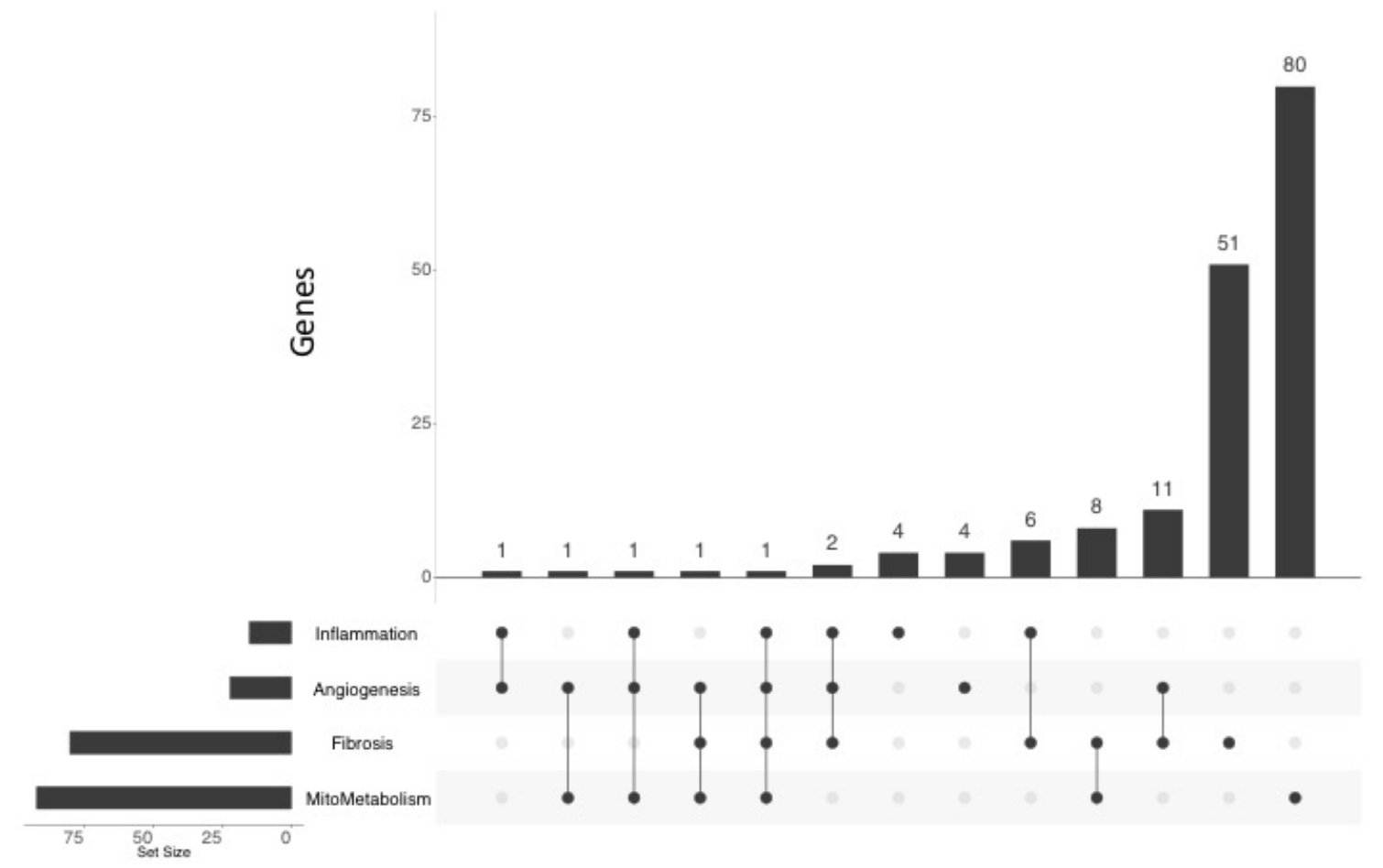

Figure 5. Intersection between inflammatory, angiogenic, fibrotic, and mitochondrial/metabolic gene expression. Data organized into a matrix and visualized using UpSetR, an R package that allows the resolution of multiple interactions to be made. Inflammation, Fibrosis, Mitochondria/Metabolism and Angiogenesis lists were compared to identify intersections in RV of the MCT rat according to function.

\section{Discussion}

The well-studied rat MCT model of PAH exhibits both RVF and pulmonary vascular remodeling. We performed several levels of phenotyping prior to the transcriptomic study. First, we created an extensive hemodynamic profile of this model, confirming that the rats were in the decompensated phased of RVF at the time the transcriptomics were measured. Careful phenotyping is, in our view, the inception point of any transcriptomic study. Evidence for RV decompensation include reduced TAPSE and increased RVEDP, and relatively low MPAP with high PVR. Moreover, through measurement of RV contractility, using PV-loop evaluation in closed-chest rats, we documented increased PRSW and PVA/EDV and a decreased Emax/Ea ratio in MCT-PAH, consistent with impaired RV-pulmonary arterial uncoupling (Table 1). These data are consistent with impaired RV myocardial contractility that is independent of both preload and afterload [32,33]. Since it is likely that the transcriptomic profile is different in RV compensation vs. decompensation, careful hemodynamic profiling is a strength of this study.

Second, we confirmed previous reports that RVF associated with PAH is characterized by increased fibrosis, inflammation and impaired angiogenesis [6]. We did this by documenting that in the MCT RV, there is increased picoserius red staining (collagen content), increased expression of the macrophage marker CD68 and decreased expression of the vascular endothelial marker CD31 (Figure 2A-C).

Third, we confirm that the RVs we studied manifested significant impairment of mitochondrial metabolism, demonstrated as a reduction in PDH activity (Figure 3A). Consistent with this, we report for the first time significant reduced activity of electron transport chain Complex I and a trend toward decreased Complex IV activity (Figure 3B,C). In aggregate, these biochemical results suggest a reduction in oxidative metabolism and a metabolic switch to aerobic glycolysis, or Warburg metabolism, in the MCT PAH model. These metabolic changes would be expected to contribute to observed reduction in RV contractile function. These metabolic findings are consistent with previous reports of 
decreased PDH activity and increased reliance on glycolysis in RV in PAH [6] Based on the therapeutic benefits of reactivating PDH using the PDK inhibitor dichloroacetate, this pathway accounts for much of the impairment of mitochondrial function in RVF-PAH [24]. Similarly, reduction of Complex I and IV activities have been reported in PAH lungs, where it is associated with a Warburg metabolic switch to uncoupled glycolysis [34,35]. However the literature on electron transport chain (ETC) function in RVF-PAH is less clear [36]. In contrast to our findings, Redout et al. showed that both expression and activity of Complex II were increased in RVF-PAH MCT rats and reported no modulation of protein expression of Complexes I, III, IV and V [36]. Conversely, in the RV of a porcine model of persistent pulmonary hypertension of newborn (PPHN), Saini-Chohan et al. showed a reduction of activity of mitochondrial complexes II and III and reduced protein levels of complexes II, III, and IV [23]. The disparities amongst studies could result from differences in the species, developmental stage and/or experimental model of PH studied. In addition, in most studies, there was a failure to subcategorize animals as having compensated versus decompensated RV. Impaired ETC activity is an additional intriguing potential contributor to RV dysfunction in PAH. Further investigation is necessary to determine if this results from dysfunction/damage to the proteins in the megacomplexes, substrate limitation, reduced mitochondrial copy number or some combination of these factors. While earlier implication of mitochondrial metabolic mechanisms in RVF were largely hypothesis driven, the current RNA sequencing data confirm a broad mitochondrial-metabolic dysregulation. Indeed, this is the most dysregulated pathway in the RV in PAH.

While the purpose of this paper was to provide an initial fingerprint of the RV transcriptome and identify dysregulated pathways, there are several robustly regulated genes in MCT RVF, which we have validated at the mRNA level (Tables 3 and 4). While we did not explore their function in this initial study, their putative functions suggest possible roles in disease progression and consequently they may merit examination as therapeutic targets and/or biomarkers on RVF. For example, relevant to RV fibrosis, the most up-regulated gene in the RV of MCT rats encodes Periostin (POSTN; 4.5-fold). Periostin is a matricellular protein expressed, which is almost exclusively expressed in fibroblasts and which can regulate extracellular matrix interactions (ECM) [37] through the binding of various proteins. Periostin interacts directly with other ECM proteins, including many that are robustly up-regulated in the MCT RV dataset [collagen I (COL1A1; 1.9-fold), collagen V (COL5A2; 1.5-fold), Fibronectin (FN1; 2.4-fold) and tenascin-C (TNC; 2.5 -fold)] [38-40]. Elevations of Periostin have already been identified in other cardiac diseases, including myocardial hypertrophy and ventricular remodelling where a fibrotic mechanism was identified [41]. Periostin has a role in the promotion of fibronectin secretion, and the fibronectin gene is also dysregulated in our dataset [39].

We placed the regulated genes in our list into enriched functional groups. Statistically-enriched terms describing functions related to "Mitochondria/Metabolism", "Fibrosis", and "Inflammation" emerged. In addition, we forced a GO:term for "Angiogenesis" into our final analysis, as this pathway was suggested by the literature to be relevant to RVF. We then surveyed independent RV microarray data from other laboratories. These studies had examined the transcriptomics of a mouse model of $\mathrm{RVH}$, induced by pulmonary artery banding, and the RV of BMPR2-PAH patients. Because both prior studies relied upon few replicates $(n=2)$, we filtered this data with a lenient, uncorrected, threshold ( $p$-value $<0.1)$. We concede that targets from this data have an unknown false-discovery rate, but note the extraordinary similarities, namely direction and relative magnitude of change, in our 4 functional dysregulated gene expression pathways (Figure 4A-D).

We further organized dysregulated genes so that those annotated in more than one of our enriched functions were identified. The gene, ANNEXIN A1 (ANXA1; 1.80-fold), emerged as being both dysregulated and relevant to mitochondrial/metabolic, fibrotic, inflammatory and angiogenic pathways. ANXA1 was downregulated -1.8-fold in RVF RVs. Anxa1 is a $\mathrm{Ca}^{2+}$-dependent, phospholipid-binding protein, which is primarily expressed in leukocytes. Glucocorticoids stimulate Anxa1 expression, which inhibits phospholipase A2, blocks eicosanoid production, various leukocyte inflammatory events (epithelial adhesion, emigration, chemotaxis, phagocytosis, respiratory burst) 
and thereby mediates an anti-inflammatory effect [42]. Conversely, decreased Anxa1 function can promote an endothelin-1 (ET-1)-induced inflammatory phenotype and PASMC proliferation in PH [43]. Anxa1 overexpression inhibits ET-1-induced inflammatory cytokine secretion and PASMC proliferation (IL-6; IL-1 $\beta$; TNF $\alpha$ ); however, Anxa1 is stimulated by IL-6, suggesting feedback between IL-6 and Anxa1 [44]. Upregulation of Anxa1 in vivo, improves atherosclerosis (decreased lesion size, inflammation, improved plaque stability) [45-47], myocardial infarction (decreased infarct size, inflammation and increased survival) [48-51] and stroke (decreased infarct size, inflammation) [52-55]. In addition to increased inflammation, Anxa1-knockout mice exhibited significant increases of fibrosis eight weeks post-myocardial infarction [56]. Anxa1 has also been detected in the mitochondria and is associated with apoptosis [57,58]. In vitro experiments show that mitochondrial Anxa1 increases upon $\mathrm{Ca}^{2+}$ overload, contributing to physical interaction between the plasma membrane and mitochondria, thereby leading to apoptosis [57]. In tumor metabolism, oxidative and reductive glutamine metabolism was found to be significantly impaired in HIF-1 $\alpha$ / Anxa1-deficient cells, and associated with lower proliferation [59]. This paradox could reflect regulation of Anxa1 function dependent of its localization (mitochondrial vs. cytoplasmic). Anxa1 deficiency has also been linked to impaired angiogenesis. Anxa1-KO mice exhibit a defect in angiogenesis and strongly impaired tumor growth. Aortic ring assays reveal that aortas from $A n x a 1^{-/-}$mice exhibit impaired endothelial cell sprouting, which can be rescued by adenoviral expression of Anxa1 [60]. Taken together, these observations confirm that Annexin A1 is involved in inflammation, fibrosis, "mitochondria/metabolism" and angiogenesis reported by our transcriptomic analysis. The fact that we have identified Anxa1 downregulation in an unbiased manner in the MCT RV implies that this gene and its product may act as a lynchpin in MCT-induced RV failure.

Numerous genes relevant to mitochondrial function and biogenesis were downregulated in RVF. Expression of Tfam, a mitochondrial transcription factor that binds to mitochondrial DNA and facilitates transcription of the mitochondrial genome, is down-regulated 0.45 -fold, in the MCT RV, consistent with impaired mitochondrial biogenesis. Tfam downregulation has been observed in human RVF [61]. The top down-regulated gene in the Mitochondria-Metabolic pathways is Cytochrome $\mathrm{P} 450$ 2E1 (Cyp2e1; - 3.8-fold expression). Cyp2e1 is a monooxygenase that is involved in metabolism of various endogenous and exogenous compounds. Cyp2e1 inhibition increases oxidative stress and apoptosis of cardiomyocyte in a murine dilated cardiomyopathy model and Cyp2e1 inhibition reduces cardiomyocyte apoptosis [62]. Thus, the observed decrease of Cyp2e1 in MCT-RV might be a cardioprotective mechanism.

Dehydrogenase/reductase 7C (Dhrs7c) was also reduced $(-2.8$ fold). Dhrs7c has been demonstrated to be downregulated by adrenergic stimulation with both phenylephrine ( $\alpha$-adrenergic) and isoproterenol ( $\beta$-adrenergic), and in several heart failure models, including biopsies from patients with heart failure [63].

Polypeptide $\mathrm{N}$-acetyl-galactose-aminyl-transferase 13 (Galnt13) was also downregulated (-2.7-fold). Galnt is also downregulated in the blood of sickle-cell disease patients with pulmonary hypertension and could distinguish patients with and without increased RVSP with 100\% accuracy [64]. Moreover, genetic association comparing patients with normal versus elevated tricuspid regurgitation jet velocity and pulmonary hypertension revealed 5 single nucleotide polymorphisms within this gene [64].

Thrombospondin4 (Thbs4; 4.4) is the highest regulated gene in the Fibroblast (and also in the Angiogenesis) functional group, and also one of the highest regulated genes overall; see independent validation in Table 3. Thbs4 is part of a family of glycoprotein that mediates cell-matrix interactions and is regulated in hypertrophic and failing hearts in various models and humans. Indeed, a single nucleotide polymorphism in the Thbs4 gene has been associated with familial premature myocardial infarction [65]. While it is not clear whether Thbs4 is regulated as part of a pathogenic or a protective response, it has been suggested as a mediator in fibrosis regulation and adaptive remodeling in the heart in response to pressure overload [66]. 
The second highest regulated gene in the Fibroblast functional list is latent-transforming growth factor beta-binding protein 2 (Ltbp2; 4.16). As their name suggests, Ltbps are critical for transforming growth factors (Tgf) to function [67]. Importantly, $T g f b 1$ and $T g f b 2$ are also upregulated in the MCT rat $\mathrm{RV}$ (1.2-fold and. 2.68 fold, respectively). Ltbp 2 is also robustly regulated in the failing RV in the SuHx model of PAH [68] and in humans this gene has been identified as upregulated in myocardial samples from heart failure patients [69].

While we have compared our data to transcript data from both mouse and human RVF, we acknowledge that this is not exhaustive and may describe specific rather than generic RV pathology and only at the transcript level. For example, comparison of our data with a recent proteomic analysis of RV from children with tetralogy of Fallot (TOF) [70] revealed only a small overlap between our data and theirs (17 proteins identified that have corresponding transcripts regulated in the rat MCT RV). While this paper also highlighted the significant enrichment of proteins involved in calcium signaling, our own functional analysis does not reveal this function as enriched. This poor concordance may reflect inherent differences between the proteome and transcriptome in these studies, or inherent biological differences between the infant human TOF RV and the "adult" rat MCT RV, or a combination of these factors, highlighting the importance of well-controlled comparative molecular analysis in order to identify pathology specific footprints.

In conclusion, transcriptomics reveals the molecular finger print of RVF in a well-phenotyped model of RV decompensation. This fingerprint is heavily characterized by mitochondrial dysfunction, and it appears to be pro-fibrotic, pro inflammatory, and anti-angiogenic. Our results confirm the previous observation made in the field [6]. Many of these dysregulated genes may be therapeutic targets or biomarkers and the changes in MCT-PAH are similar to those observed in a small sample of human PAH RVs, facilitating translation of preclinic studies. Proteomic and metabolic correlates of the disordered pathways identified by transcriptomics will be essential to evaluate which gene expression abnormalities are most relevant to disease pathogenesis or are most relevant to therapeutic targeting

\section{Materials and Methods}

Full Materials and Methods are available in the Supplementary Materials.

\subsection{Monocrotaline-Induced PAH Animal Model}

Experiments were conducted in accordance with the Canadian Council on Animal Care and approved by the Queen's University Animal Care Committee (017-1714; 15 February 2018). Male Sprague-Dawley rats ( $270 \mathrm{~g}$, Charles River, Quebec, QC, Canada) received a single subcutaneous injection of monocrotaline (MCT; $60 \mathrm{mg} / \mathrm{kg}$; C2401; Sigma-Aldrich, Oakville, ON, Canada), as previously described [27]. For additional detail, see Supplementary Materials.

\subsection{Hemodynamic Parameters}

Echocardiography: Non-invasive doppler, 2-dimensional, M-mode, tissue imaging and pulsed wave echocardiography were performed on anesthetized animals $(5 \%$ isoflurane induction and maintained with $2 \%$ during procedures) using a high-frequency ultrasound system (Vevo 2100; Visual Sonics, Toronto, ON, Canada), as previously described [19] (see Supplementary Materials).

\subsection{Right Heart Catheterization (RHC)}

Invasive closed-chest RHC was performed to obtain RV pressure-volume (PV) loops. Briefly, animals were anesthetized with $5 \%$ isoflurane induction and maintained with $3 \%$ during procedures. During catheterization, rats were intubated and ventilated. A high-fidelity catheter (Scisence pressure-volume catheter; Transonic, London, ON, Canada) was advanced into the right ventricle (RV) via the jugular vein and right atria, in closed-chest rats. RV pressure and volume were recorded continuously using Scisense ADV500 Pressure-Volume Measurement System (Transonic) and LabScribe2 software (iWorx, Dover, NH, USA). For additional details, see Supplementary Materials. 


\subsection{Immunoblotting and Histology}

See Supplementary Materials.

\subsection{Mitochondrial Enzyme Activity}

The activity of Pyruvate dehydrogenase (PDH), Complex IV and I were measured using enzyme activity dipstick assays from abcam (Cambridge, UK) according to the manufacturer's recommendations (ab 109878; ab109720; ab109882) using 30-75 $\mu \mathrm{g}$ of protein extract, see Supplementary Materials.

\subsection{RNA Sequencing}

Right ventricles were dissected free from the LV and vasculature and ground with a mortar and pestle in liquid nitrogen. total RNA was extracted in TrIzol using Zymo DirectZol columns (Zymotech Inc., Austin, TX, USA). Libraries were generated using an Illumina RiboGold ribodepletion and Truseq stranded LT library generation kit (Illumina Inc., San Diego, CA, USA), and sequenced using the Illumina NextSeq550 Sequencer (Illumina). For additional details, see Supplementary Materials.

\subsection{Statistical Analysis}

All of the data are reported as mean \pm SEM. Differences between groups were calculated using a two-tailed, Student's $t$-test, corrected for multiple comparisons (Bonferroni). For additional details, see Supplementary Materials.

Supplementary Materials: Supplementary materials can be found at http:/ / www.mdpi.com/1422-0067/19/9/ 2730/s1.

Author Contributions: Designed the work: F.P., C.C.T.H. and S.L.A. Performed experiments: F.P., C.C.T.H., K.J.D.-S. Analyzed and interpreted data: F.P., K.J.D.-S., C.C.T.H. and S.L.A.; Drafted the work: F.P., C.C.T.H. and S.L.A. Revised the work critically: F.P., K.J.D.-S., C.C.T.H., S.L.A. Final approval of the version to be published: F.P., C.C.T.H., K.J.D.-S., J.S. and S.L.A.

Funding: This study was supported in part by: U.S. National Institutes of Health (NIH) grants NIH 1R01HL113003-01A1 (S.L.A.) and NIH 2R01HL071115-06A1 (S.L.A), Canada Foundation for Innovation 229252 and 33012 (S.L.A.), Tier 1 Canada Research Chair in Mitochondrial Dynamics and Translational Medicine 950-229252 (S.L.A.), Canadian Institutes of Health Research (CIHR) Foundation Grant CIHR FDN 143261, the William J. Henderson Foundation (S.L.A.), CIHR Postdoctoral Fellowship 382118 (KDS) the Canadian Vascular Network Scholar Award (F.P; KDS) and QCPU, Queen's Cardiopulmonary Unit.

Conflicts of Interest: The authors declare no conflict of interest.

\section{References}

1. Vonk Noordegraaf, A.; Galiè, N. The role of the right ventricle in pulmonary arterial hypertension. Eur. Respir. Rev. 2011, 20, 243-253. [CrossRef] [PubMed]

2. Van de Veerdonk, M.C.; Kind, T.; Marcus, J.T.; Mauritz, G.J.; Heymans, M.W.; Bogaard, H.J.; Boonstra, A.; Marques, K.M.; Westerhof, N.; Vonk-Noordegraaf, A. Progressive right ventricular dysfunction in patients with pulmonary arterial hypertension responding to therapy. J. Am. Coll. Cardiol. 2011, 58, 2511-2519. [CrossRef] [PubMed]

3. Wijeratne, D.T.; Lajkosz, K.; Brogly, S.B.; Lougheed, M.D.; Jiang, L.; Housin, A.; Barber, D.; Johnson, A.; Doliszny, K.M.; Archer, S.L. Increasing Incidence and Prevalence of World Health Organization Groups 1 to 4 Pulmonary Hypertension. Circ. Cardiovasc. Qual. Outcomes 2018, 11, e003973. [CrossRef] [PubMed]

4. Thenappan, T.; Ormiston, M.L.; Ryan, J.J.; Archer, S.L. Pulmonary arterial hypertension: Pathogenesis and clinical management. BMJ 2018, 360, j5492. [CrossRef] [PubMed]

5. Sydykov, A.; Mamazhakypov, A.; Petrovic, A.; Kosanovic, D.; Sarybaev, A.S.; Weissmann, N.; Ghofrani, H.A.; Schermuly, R.T. Inflammatory Mediators Drive Adverse Right Ventricular Remodeling and Dysfunction and Serve as Potential Biomarkers. Front. Physiol. 2018, 9, 609. [CrossRef] [PubMed]

6. Ryan, J.J.; Archer, S.L. The Right Ventricle in Pulmonary Arterial Hypertension: Disorders of Metabolism, Angiogenesis and Adrenergic Signaling in Right Ventricular Failure. Circ. Res. 2014, 115, 176-188. [CrossRef] [PubMed] 
7. Rain, S.; Andersen, S.; Najafi, A.; Gammelgaard, S.J.; da Silva Gonçalves, B.D.; Handoko, M.L.; Bogaard, H.J.; Vonk-Noordegraaf, A.; Andersen, A.; van der Velden, J.; et al. Right Ventricular Myocardial Stiffness in Experimental Pulmonary Arterial HypertensionClinical Perspective. Circ. Hear Fail. 2016, 9, e002636. [CrossRef] [PubMed]

8. $\quad$ Freed, B.H.; Gomberg-Maitland, M.; Chandra, S.; Mor-Avi, V.; Rich, S.; Archer, S.L.; Jamison, E.B., Jr.; Lang, R.M.; Patel, A.R. Late gadolinium enhancement cardiovascular magnetic resonance predicts clinical worsening in patients with pulmonary hypertension. J. Cardiovasc. Magn. Reson. 2012, 14, 11. [CrossRef] [PubMed]

9. Blyth, K.G.; Groenning, B.A.; Martin, T.N.; Foster, J.E.; Mark, P.B.; Dargie, H.J.; Peacock, A.J. Contrast enhanced-cardiovascular magnetic resonance imaging in patients with pulmonary hypertension. Eur. Heart J. 2005, 26, 1993-1999. [CrossRef] [PubMed]

10. Safdar, Z.; Tamez, E.; Chan, W.; Arya, B.; Ge, Y.; Deswal, A.; Bozkurt, B.; Frost, A.; Entman, M. Circulating Collagen Biomarkers as Indicators of Disease Severity in Pulmonary Arterial Hypertension. JACC Hear Fail. 2014, 2, 412-421. [CrossRef] [PubMed]

11. Sun, X.-Q.; Zhang, R.; Zhang, H.-D.; Yuan, P.; Wang, X.-J.; Zhao, Q.-H.; Wang, L.; Jiang, R.; Jan Bogaard, H.; Jing, Z.-C. Reversal of right ventricular remodeling by dichloroacetate is related to inhibition of mitochondria-dependent apoptosis. Hypertens. Res. 2016, 39, 302-311. [CrossRef] [PubMed]

12. Mendes-Ferreira, P.; Maia-Rocha, C.; Adão, R.; Mendes, M.J.; Santos-Ribeiro, D.; Alves, B.S.; Cerqueira, R.J.; Castro-Chaves, P.; Lourenço, A.P.; De Keulenaer, G.W.; et al. Neuregulin-1 improves right ventricular function and attenuates experimental pulmonary arterial hypertension. Cardiovasc. Res. 2016, 109, 44-54. [CrossRef] [PubMed]

13. Harhay, M.O.; Tracy, R.P.; Bagiella, E.; Barr, R.G.; Pinder, D.; Hundley, W.G.; Bluemke, D.A.; Kronmal, R.A.; Lima, J.A.; Kawut, S.M. Relationship of CRP, IL-6, and fibrinogen with right ventricular structure and function: The MESA-Right Ventricle Study. Int. J. Cardiol. 2013, 168, 3818-3824. [CrossRef] [PubMed]

14. Prins, K.W.; Archer, S.L.; Pritzker, M.; Rose, L.; Weir, E.K.; Sharma, A.; Thenappan, T. Interleukin-6 is independently associated with right ventricular function in pulmonary arterial hypertension. J. Hear Lung Transplant. 2018, 37, 376-384. [CrossRef] [PubMed]

15. Mathai, S.C.; Hassoun, P.M. Pulmonary arterial hypertension in connective tissue diseases. Heart Fail. Clin. 2012, 8, 413-425. [CrossRef] [PubMed]

16. Hilfiker-Kleiner, D.; Landmesser, U.; Drexler, H. Molecular Mechanisms in Heart Failure: Focus on Cardiac Hypertrophy, Inflammation, Angiogenesis, and Apoptosis. J. Am. Coll. Cardiol. 2006, 48, A56-A66. [CrossRef]

17. Suthahar, N.; Meijers, W.C.; Silljé, H.H.W.; de Boer, R.A. From Inflammation to Fibrosis-Molecular and Cellular Mechanisms of Myocardial Tissue Remodelling and Perspectives on Differential Treatment Opportunities. Curr. Heart Fail. Rep. 2017, 14, 235-250. [CrossRef] [PubMed]

18. Voelkel, N.F.; Gomez-Arroyo, J.; Abbate, A.; Bogaard, H.J. Mechanisms of right heart failure-A work in progress and a plea for failure prevention. Pulm. Circ. 2013, 3, 137-143. [CrossRef] [PubMed]

19. Potus, F.; Ruffenach, G.; Dahou, A.; Thebault, C.; Breuils-Bonnet, S.; Tremblay, Ė.; Nadeau, V.; Paradis, R.; Graydon, C.; Wong, R.; et al. Downregulation of miR-126 Contributes to the Failing Right Ventricle in Pulmonary Arterial Hypertension. Circulation 2015, 132, 932-943. [CrossRef] [PubMed]

20. Zhao, Y.D.; Courtman, D.W.; Ng, D.S.; Robb, M.J.; Deng, Y.P.; Trogadis, J.; Han, R.N.; Stewart, D.J. Microvascular Regeneration in Established Pulmonary Hypertension by Angiogenic Gene Transfer. Am. J. Respir. Cell Mol. Biol. 2006, 35, 182-189. [CrossRef] [PubMed]

21. Partovian, C.; Adnot, S.; Raffestin, B.; Louzier, V.; Levame, M.; Mavier, I.M.; Lemarchand, P.; Eddahibi, S. Adenovirus-Mediated Lung Vascular Endothelial Growth Factor Overexpression Protects against Hypoxic Pulmonary Hypertension in Rats. Am. J. Respir. Cell Mol. Biol. 2000, 23, 762-771. [CrossRef] [PubMed]

22. Reddy, S.; Bernstein, D. Molecular Mechanisms of Right Ventricular Failure. Circulation 2015, 132, $1734-1742$. [CrossRef] [PubMed]

23. Saini-Chohan, H.K.; Dakshinamurti, S.; Taylor, W.A.; Shen, G.X.; Murphy, R.; Sparagna, G.C.; Hatch, G.M. Persistent pulmonary hypertension results in reduced tetralinoleoyl-cardiolipin and mitochondrial complex II + III during the development of right ventricular hypertrophy in the neonatal pig heart. Am. J. Physiol. Circ. Physiol. 2011, 301, H1415-H1424. [CrossRef] [PubMed] 
24. Piao, L.; Fang, Y.-H.; Cadete, V.J.J.; Wietholt, C.; Urboniene, D.; Toth, P.T.; Marsboom, G.; Zhang, H.J.; Haber, I.; Rehman, J.; et al. The inhibition of pyruvate dehydrogenase kinase improves impaired cardiac function and electrical remodeling in two models of right ventricular hypertrophy: Resuscitating the hibernating right ventricle. J. Mol. Med. 2010, 88, 47-60. [CrossRef] [PubMed]

25. Tian, L.; Neuber-Hess, M.; Mewburn, J.; Dasgupta, A.; Dunham-Snary, K.; Wu, D.; Chen, K.H.; Hong, Z.; Sharp, W.W.; Kutty, S.; et al. Ischemia-induced Drp1 and Fis1-mediated mitochondrial fission and right ventricular dysfunction in pulmonary hypertension. J. Mol. Med. 2017, 95, 381-393. [CrossRef] [PubMed]

26. Liu, A.; Philip, J.; Vinnakota, K.C.; Van den Bergh, F.; Tabima, D.M.; Hacker, T.; Beard, D.A.; Chesler, N.C. Estrogen maintains mitochondrial content and function in the right ventricle of rats with pulmonary hypertension. Physiol. Rep. 2017, 5, e13157. [CrossRef] [PubMed]

27. Tian, L.; Potus, F.; Wu, D.; Dasgupta, A.; Chen, K.H.; Mewburn, J.; Lima, P.; Archer, S.L. Increased Drp1-Mediated Mitochondrial Fission Promotes Proliferation and Collagen Production by Right Ventricular Fibroblasts in Experimental Pulmonary Arterial Hypertension. Front. Physiol. 2018, 9, 828. [CrossRef] [PubMed]

28. Meyrick, B.; Gamble, W.; Reid, L. Development of Crotalaria pulmonary hypertension: Hemodynamic and structural study. Am. J. Physiol. Circ. Physiol. 1980, 239, H692-H702. [CrossRef] [PubMed]

29. Huang, D.W.; Sherman, B.T.; Lempicki, R.A. Systematic and integrative analysis of large gene lists using DAVID bioinformatics resources. Nat. Protoc. 2009, 4, 44-57. [CrossRef] [PubMed]

30. Grosse Kreymborg, K.; Uchida, S.; Gellert, P.; Schneider, A.; Boettger, T.; Voswinckel, R.; Wietelmann, A.; Szibor, M.; Weissmann, N.; Ghofrani, A.H.; et al. Identification of right heart-enriched genes in a murine model of chronic outflow tract obstruction. J. Mol. Cell. Cardiol. 2010, 49, 598-605. [CrossRef] [PubMed]

31. Hemnes, A.R.; Brittain, E.L.; Trammell, A.W.; Fessel, J.P.; Austin, E.D.; Penner, N.; Maynard, K.B.; Gleaves, L.; Talati, M.; Absi, T.; et al. Evidence for Right Ventricular Lipotoxicity in Heritable Pulmonary Arterial Hypertension. Am. J. Respir. Crit. Care Med. 2014, 189, 325-334. [CrossRef] [PubMed]

32. Naeije, R.; Manes, A. The right ventricle in pulmonary arterial hypertension. Eur. Respir. Rev. 2014, 23, 476-487. [CrossRef] [PubMed]

33. Nishio, R.; Sasayama, S.; Matsumori, A. Left ventricular pressure-volume relationship in a murine model of congestive heart failure due to acute viral myocarditis. J. Am. Coll. Cardiol. 2002, 40, 1506-1514. [CrossRef]

34. Yu, Q.; Chan, S.Y. Mitochondrial and Metabolic Drivers of Pulmonary Vascular Endothelial Dysfunction in Pulmonary Hypertension. Adv. Exp. Med. Biol. 2017, 967, 373-383. [CrossRef] [PubMed]

35. Rafikov, R.; Sun, X.; Rafikova, O.; Meadows, M.L.; Desai, A.A.; Khalpey, Z.; Yuan, J.X.; Fineman, J.R.; Black, S.M. Complex I dysfunction underlies the glycolytic switch in pulmonary hypertensive smooth muscle cells. Redox. Biol. 2015, 6, 278-286. [CrossRef] [PubMed]

36. Redout, E.; Wagner, M.; Zuidwijk, M.; Boer, C.; Musters, R.J.; van Hardeveld, C.; Paulus, W.J.; Simonides, W.S. Right-ventricular failure is associated with increased mitochondrial complex II activity and production of reactive oxygen species. Cardiovasc. Res. 2007, 75, 770-781. [CrossRef] [PubMed]

37. Tracy, L.E.; Minasian, R.A.; Caterson, E.J. Extracellular Matrix and Dermal Fibroblast Function in the Healing Wound. Adv. Wound Care 2016, 5, 119-136. [CrossRef] [PubMed]

38. Norris, R.A.; Damon, B.; Mironov, V.; Kasyanov, V.; Ramamurthi, A.; Moreno-Rodriguez, R.; Trusk, T.; Potts, J.D.; Goodwin, R.L.; Davis, J.; et al. Periostin regulates collagen fibrillogenesis and the biomechanical properties of connective tissues. J. Cell. Biochem. 2007, 101, 695-711. [CrossRef] [PubMed]

39. Liu, A.Y.; Zheng, H.; Ouyang, G. Periostin, a multifunctional matricellular protein in inflammatory and tumor microenvironments. Matrix Biol. 2014, 37, 150-156. [CrossRef] [PubMed]

40. Kii, I.; Nishiyama, T.; Li, M.; Matsumoto, K.; Saito, M.; Amizuka, N.; Kudo, A. Incorporation of Tenascin-C into the Extracellular Matrix by Periostin Underlies an Extracellular Meshwork Architecture. J. Biol. Chem. 2010, 285, 2028-2039. [CrossRef] [PubMed]

41. Zhao, S.; Wu, H.; Xia, W.; Chen, X.; Zhu, S.; Zhang, S.; Shao, Y.; Ma, W.; Yang, D.; Zhang, J. Periostin expression is upregulated and associated with myocardial fibrosis in human failing hearts. J. Cardiol. 2014, 63, 373-378. [CrossRef] [PubMed]

42. Gavins, F.N.E.; Hickey, M.J. Annexin A1 and the regulation of innate and adaptive immunity. Front. Immunol. 2012, 3, 354. [CrossRef] [PubMed] 
43. He, J.; Yi, B.; Chen, Y.; Huang, Q.; Wang, H.; Lu, K.; Fu, W. The ET-1-mediated carbonylation and degradation of ANXA1 induce inflammatory phenotype and proliferation of pulmonary artery smooth muscle cells in HPS. PLoS ONE 2017, 12, e0175443. [CrossRef] [PubMed]

44. De Coupade, C.; Ajuebor, M.N.; Russo-Marie, F.; Perretti, M.; Solito, E. Cytokine modulation of liver annexin 1 expression during experimental endotoxemia. Am. J. Pathol. 2001, 159, 1435-1443. [CrossRef]

45. Fredman, G.; Kamaly, N.; Spolitu, S.; Milton, J.; Ghorpade, D.; Chiasson, R.; Kuriakose, G.; Perretti, M.; Farokzhad, O.; Tabas, I. Targeted nanoparticles containing the proresolving peptide Ac2-26 protect against advanced atherosclerosis in hypercholesterolemic mice. Sci. Transl. Med. 2015, 7, 275ra20. [CrossRef] [PubMed]

46. Drechsler, M.; de Jong, R.; Rossaint, J.; Viola, J.R.; Leoni, G.; Wang, J.M.; Grommes, J.; Hinkel, R.; Kupatt, C.; Weber, C.; et al. Annexin A1 counteracts chemokine-induced arterial myeloid cell recruitment. Circ. Res. 2015, 116, 827-835. [CrossRef] [PubMed]

47. Kusters, D.H.M.; Chatrou, M.L.; Willems, B.A.G.; De Saint-Hubert, M.; Bauwens, M.; van der Vorst, E.; Bena, S.; Biessen, E.A.; Perretti, M.; Schurgers, L.J.; et al. Pharmacological Treatment with Annexin A1 Reduces Atherosclerotic Plaque Burden in LDLR-/- Mice on Western Type Diet. PLoS ONE 2015, 10, e0130484. [CrossRef] [PubMed]

48. D’Amico, M.; Di Filippo, C.; La, M.; Solito, E.; McLean, P.G.; Flower, R.J.; Oliani, S.M.; Perretti, M. Lipocortin 1 reduces myocardial ischemia-reperfusion injury by affecting local leukocyte recruitment. FASEB J. 2000, 14, 1867-1869. [CrossRef] [PubMed]

49. Gavins, F.N.E.; Kamal, A.M.; D'Amico, M.; Oliani, S.M.; Perretti, M. Formyl-peptide receptor is not involved in the protection afforded by annexin 1 in murine acute myocardial infarct. FASEB J. 2005, 19, 100-102. [CrossRef] [PubMed]

50. La, M.; D’Amico, M.; Bandiera, S.; Di Filippo, C.; Oliani, S.M.; Gavins, F.N.; Flower, R.J.; Perretti, M. Annexin 1 peptides protect against experimental myocardial ischemia-reperfusion: Analysis of their mechanism of action. FASEB J. 2001, 15, 2247-2256. [CrossRef] [PubMed]

51. Dalli, J.; Consalvo, A.P.; Ray, V.; Di Filippo, C.; D'Amico, M.; Mehta, N.; Perretti, M. Proresolving and tissue-protective actions of annexin A1-based cleavage-resistant peptides are mediated by formyl peptide receptor 2/lipoxin A4 receptor. J. Immunol. 2013, 190, 6478-6487. [CrossRef] [PubMed]

52. Gavins, F.N.E.; Dalli, J.; Flower, R.J.; Granger, D.N.; Perretti, M. Activation of the annexin 1 counter-regulatory circuit affords protection in the mouse brain microcirculation. FASEB J. 2007, 21, 1751-1758. [CrossRef] [PubMed]

53. Relton, J.K.; Strijbos, P.J.; O'Shaughnessy, C.T.; Carey, F.; Forder, R.A.; Tilders, F.J.; Rothwell, N.J. Lipocortin-1 is an endogenous inhibitor of ischemic damage in the rat brain. J. Exp. Med. 1991, 174, 305-310. [CrossRef] [PubMed]

54. Smith, H.K.; Gil, C.D.; Oliani, S.M.; Gavins, F.N.E. Targeting formyl peptide receptor 2 reduces leukocyte-endothelial interactions in a murine model of stroke. FASEB J. 2015, 29, 2161-2171. [CrossRef] [PubMed]

55. Vital, S.A.; Becker, F.; Holloway, P.M.; Russell, J.; Perretti, M.; Granger, D.N.; Gavins, F.N. Formyl-Peptide Receptor 2/3/Lipoxin A4 Receptor Regulates Neutrophil-Platelet Aggregation and Attenuates Cerebral Inflammation: Impact for Therapy in Cardiovascular Disease. Circulation 2016, 133, 2169-2179. [CrossRef] [PubMed]

56. Qin, C.X.; Finlayson, S.B.; Al-Sharea, A.; Tate, M.; De Blasio, M.J.; Deo, M.; Rosli, S.; Prakoso, D.; Thomas, C.J.; Kiriazis, H.; et al. Endogenous Annexin-A1 Regulates Haematopoietic Stem Cell Mobilisation and Inflammatory Response Post Myocardial Infarction in Mice In Vivo. Sci. Rep. 2017, 7, 16615. [CrossRef] [PubMed]

57. Babiychuk, E.B.; Atanassoff, A.P.; Monastyrskaya, K.; Brandenberger, C.; Studer, D.; Allemann, C.; Draeger, A. The Targeting of Plasmalemmal Ceramide to Mitochondria during Apoptosis. PLoS ONE 2011, 6, e23706. [CrossRef] [PubMed]

58. Ohnishi, M.; Tokuda, M.; Masaki, T.; Fujimura, T.; Tai, Y.; Itano, T.; Matsui, H.; Ishida, T.; Konishi, R.; Takahara, J.; et al. Involvement of annexin-I in glucose-induced insulin secretion in rat pancreatic islets. Endocrinology 1995, 136, 2421-2426. [CrossRef] [PubMed] 
59. Rohwer, N.; Bindel, F.; Grimm, C.; Lin, S.J.; Wappler, J.; Klinger, B.; Blüthgen, N.; Du Bois, I.; Schmeck, B.; Lehrach, H.; et al. Annexin A1 sustains tumor metabolism and cellular proliferation upon stable loss of HIF1A. Oncotarget 2016, 7, 6693-6710. [CrossRef] [PubMed]

60. Yi, M.; Schnitzer, J.E. Impaired tumor growth, metastasis, angiogenesis and wound healing in annexin A1-null mice. Proc. Natl. Acad. Sci. USA 2009, 106, 17886-17891. [CrossRef] [PubMed]

61. Karamanlidis, G.; Bautista-Hernandez, V.; Fynn-Thompson, F.; Del Nido, P.; Tian, R. Impaired Mitochondrial Biogenesis Precedes Heart Failure in Right Ventricular Hypertrophy in Congenital Heart Disease. Circ. Hear Fail. 2011, 4, 707-713. [CrossRef] [PubMed]

62. Zhang, W.; Lu, D.; Dong, W.; Zhang, L.; Zhang, X.; Quan, X.; Ma, C.; Lian, H.; Zhang, L. Expression of CYP2E1 increases oxidative stress and induces apoptosis of cardiomyocytes in transgenic mice. FEBS J. 2011, 278, 1484-1492. [CrossRef] [PubMed]

63. Lu, B.; Tigchelaar, W.; Ruifrok, W.P.T.; van Gilst, W.H.; de Boer, R.A.; Silljé, H.H. DHRS7c, a novel cardiomyocyte-expressed gene that is down-regulated by adrenergic stimulation and in heart failure. Eur. J. Heart Fail. 2012, 14, 5-13. [CrossRef] [PubMed]

64. Maron, B.A.; Machado, R.F.; Shimoda, L. Pulmonary Vascular and Ventricular Dysfunction in the Susceptible Patient (2015 Grover Conference Series). Pulm. Circ. 2016, 6, 426-438. [CrossRef] [PubMed]

65. Topol, E.J.; McCarthy, J.; Gabriel, S.; Moliterno, D.J.; Rogers, W.J.; Newby, L.K.; Freedman, M.; Metivier, J.; Cannata, R.; O'Donnell, C.J.; et al. Single nucleotide polymorphisms in multiple novel thrombospondin genes may be associated with familial premature myocardial infarction. Circulation 2001, 104, 2641-2644. [CrossRef] [PubMed]

66. Frolova, E.G.; Sopko, N.; Blech, L.; Popovic, Z.B.; Li, J.; Vasanji, A.; Drumm, C.; Krukovets, I.; Jain, M.K.; Penn, M.S.; et al. Thrombospondin-4 regulates fibrosis and remodeling of the myocardium in response to pressure overload. FASEB J. 2012, 26, 2363-2373. [CrossRef] [PubMed]

67. Oklü, R.; Hesketh, R. The latent transforming growth factor beta binding protein (LTBP) family. Biochem. J. 2000, 352 Pt 3, 601-610. [CrossRef]

68. Legchenko, E.; Chouvarine, P.; Borchert, P.; Fernandez-Gonzalez, A.; Snay, E.; Meier, M.; Maegel, L.; Mitsialis, S.A.; Rog-Zielinska, E.A.; Kourembanas, S.; et al. PPAR $\gamma$ agonist pioglitazone reverses pulmonary hypertension and prevents right heart failure via fatty acid oxidation. Sci. Transl. Med. 2018, 10, eaao0303. [CrossRef] [PubMed]

69. Bai, Y.; Zhang, P.; Zhang, X.; Huang, J.; Hu, S.; Wei, Y. LTBP-2 acts as a novel marker in human heart failure-A preliminary study. Biomarkers 2012, 17, 407-415. [CrossRef] [PubMed]

70. Bond, A.R.; Iacobazzi, D.; Abdul-Ghani, S.; Ghorbel, M.; Heesom, K.; Wilson, M.; Gillett, C.; George, S.J.; Caputo, M.; Suleiman, S.; et al. Changes in contractile protein expression are linked to ventricular stiffness in infants with pulmonary hypertension or right ventricular hypertrophy due to congenital heart disease. Open Hear 2018, 5, e000716. [CrossRef] [PubMed] 